\title{
Factors controlling the accelerated expansion of Imja Lake, Mount Everest region, Nepal
}

\author{
Sudeep THAKURI, ${ }^{1,2}$ Franco SALERNO, ${ }^{1,3}$ Tobias BOLCH, ${ }^{4,5}$ Nicolas GUYENNON, ${ }^{1}$ \\ Gianni TARTARI ${ }^{1,3}$
}

\author{
${ }^{1}$ National Research Council, Water Research Institute (IRSA-CNR), Brugherio, Italy \\ ${ }^{2}$ Department of Earth Sciences 'Ardito Desio', University of Milan, Milan, Italy \\ ${ }^{3}$ Ev-K2-CNR Association, Bergamo, Italy \\ ${ }^{4}$ Department of Geography, University of Zürich, Zürich, Switzerland \\ ${ }^{5}$ Institute for Cartography, Technische Universität Dresden, Dresden, Germany \\ Correspondence: Sudeep Thakuri<thakuri@irsa.cnr.it>
}

\begin{abstract}
This study explores the link between area increase of Imja Tsho (Lake) and changes of Imja Glacier (area $\sim 25 \mathbf{k m}^{2}$ ) under the influence of climate change using multitemporal satellite imagery and local climate data. Between 1962 and 2013, Imja Lake expanded from $0.03 \pm 0.01$ to $1.35 \pm 0.05 \mathrm{~km}^{2}$ at a rate of $0.026 \pm 0.001 \mathrm{~km}^{2} \mathrm{a}^{-1}$. The mean glacier-wide flow velocity was $37 \pm 30 \mathrm{~m} \mathrm{a}^{-1}$ during $1992-93$ and $23 \pm 15 \mathrm{ma}^{-1}$ during 2013-14, indicating a decreasing velocity. $A$ mean elevation change of $-1.29 \pm 0.71 \mathrm{~m} \mathrm{a}^{-1}$ was observed over the lower part of the glacier in the period 2001-14, with a rate of $-1.06 \pm 0.63 \mathrm{ma}^{-1}$ in 2001-08 and $-1.56 \pm 0.80 \mathrm{~m} \mathrm{a}^{-1}$ in 2008-14. We conclude that the decrease in flow velocity is mainly associated with reduced accumulation due to a decrease in precipitation during the last few decades. Furthermore, glacier ablation has increased due to increasing maximum temperatures during the post-monsoon months. Decreased glacier flow velocities and increased mass losses induce the formation and subsequent expansion of glacial lakes under favourable topographic conditions.
\end{abstract}

KEYWORDS: climate change, glacier flow, glacier hazards, mountain glaciers, remote sensing

\section{INTRODUCTION}

The Everest region is characterized by large debris-covered glaciers (Fujii and Higuchi, 1977) and many glacial lakes (Gardelle and others, 2011; Salerno and others, 2012). According to Salerno and others (2012), three types of glacial lakes are present in this region: (1) supraglacial lakes, which evolved and are located on the surfaces of glaciers; (2) proglacial lakes, which are moraine-dammed lakes in contact with glaciers; and (3) unconnected lakes, which are not directly connected to glaciers, but may have a glacier located in their basin. Previous studies revealed that the area of proglacial lakes on the southern slopes of Mount Everest has increased since the early 1960s (Bolch and others, 2008a; Tartari and others, 2008; Gardelle and others, 2011). Many studies have indicated that current moraine- or ice-dammed lakes are the result of coalescence and growth of supraglacial lakes (e.g. Fujita and others, 2009; Watanabe and others, 2009; Thompson and others, 2012). Such lakes pose a potential threat of glacial lake outburst flood (GLOF; e.g. Richardson and Reynolds, 2000; Bajracharya and others, 2007; Benn and others, 2012), with consequent loss of human lives and property in the downstream valley. Imja Tsho (Lake) is one of several proglacial lakes in the Everest region that evolved in the early 1960 s from a small pond and subsequently expanded (Bolch and others, 2008a; SomosValenzuela and others, 2014). This lake has been of great research interest due to its potential risk (e.g. Yamada, 1998; Bajracharya and others, 2007; Fujita and others, 2009).

Glacier flow velocity and elevation change are key variables that reflect a glacier's status and provide information about the influence of ongoing climate change (Cuffey and Paterson, 2010; Paul and others, 2015). In the Everest region, using the geodetic mass-balance approach, Bolch and others (2011) studied the mass change of ten glaciers, which exhibited significant mass loss of $0.32 \pm 0.08 \mathrm{mw}$. e. $\mathrm{a}^{-1}$ during $1970-2007$ and $0.79 \pm$ $0.52 \mathrm{~m} w . e .^{-1}$ during 2002-07. However, Gardelle and others (2013) reported a lower rate of mass loss $(0.41 \pm$ $0.21 \mathrm{mw}$ e. $\mathrm{a}^{-1}$ ) during 1999-2011. Other studies (Bolch and others, 2008a; Scherler and others, 2008; Quincey and others, 2009; Peters and others, 2010) addressed the flow velocity of selected glaciers over a short time span (from days to a few years). These researchers reported that the present ice stagnation in the lower ablation region of glaciers is attributable to low flow velocity generated by a generally negative mass balance, although it is not yet clear how the velocities are evolving due to a lack of continuous measurements. Quincey and others (2009) measured the glacier velocities between 1992 and 2002 in this region. They reported a general deceleration of the glaciers and demonstrated that the debris-covered stagnant tongues are characterized by very low $\left(<2^{\circ}\right)$ surface gradients, suggesting strong topographic control on glacier flow in the region.

Previous studies addressed the evolution of glacial lakes in the Everest region (Tartari and others, 2008; Gardelle and others, 2011; Somos-Valenzuela and others, 2014), their potential hazard or risk (Yamada, 1998; Bolch and others, 2008a; Watanabe and others, 2009; Benn and others, 2012) and the condition of formation (Benn and others, 2001; Fujita and others, 2009; Sakai and Fujita, 2010; Salerno and others, 2012) using field and remote-sensing methods. Bolch and others (2008a), Quincey and others (2009) and Salerno and others (2012) noted that reductions in the flow velocities are a possible trigger for the formation of glacial 
lakes. However, there are still no studies addressing the link between contemporary variations in glacier properties and lake surface evolution.

In this paper, we present variations of Imja Glacier and Imja Lake between the 1960s and 2014, with particular emphasis on the previous two decades, with the aim of linking the glacier's properties to the evolution of the lake's surface area. In addition, we examine local temperature and precipitation, and discuss how these variables may potentially drive such changes.

\section{STUDY AREA}

Imja Glacier $\left(27.86-27.96^{\circ} \mathrm{N}, 86.90-86.98^{\circ} \mathrm{E}\right)$, covering an area of $24.7 \mathrm{~km}^{2}$ in 2013, is located in Sagarmatha (Mount Everest) National Park (SNP), which contains the upper catchment area of the Dudh Koshi river in the Nepalese Himalaya (Fig. 1). The SNP is the world's highest protected area and was visited by more than 30000 tourists in 2008 (Salerno and others, 2010a,b, 2013). The park has an area of $1148 \mathrm{~km}^{2}$ and lies at elevations ranging from 2845 to 8848 m a.s.l. (Manfredi and others, 2010). In this study, we investigate three glacial branches that flow northward (Amphu Lapcha), westward (Imja) and southwestward (Lhotse Shar) and are collectively referred to as Imja Glacier in accordance with the naming of this complex by Salerno and others (2008), Thakuri and others (2014) and the Global Land Ice Measurements from Space (GLIMS) database (GLIMS and NSIDC, 2005). Although these three glaciers display an ice divide in the accumulation area, they were connected to one another at their tongues; however, in recent years, the tongue of the Amphu Lapcha branch has become disconnected from the Imja-Lhotse Shar branch.

The Everest region is one of the most heavily glacierized parts of the Himalaya (Scherler and others, 2011). Most of the large glaciers are debris-covered, i.e. the ablation zone is partially covered with debris (Fujii and Higuchi, 1977). Thakuri and others (2014) investigated a total glacier surface area of $350 \mathrm{~km}^{2}$ in the SNP (in 2011), covering 29 glaciers $>1 \mathrm{~km}^{2}$ and other small glaciers $<1 \mathrm{~km}^{2}$. They reported a glacier surface area loss of $13 \%$, a mean terminus retreat of $\sim 400 \mathrm{~m}$, a rise in the snowline elevation of $180 \mathrm{~m}$ and a $17 \%$ increase in debris coverage from the 1960s to 2011 on the southern slope of Mount Everest. Salerno and others (2012) reported a total of 624 lakes in the SNP: 17 proglacial, 437 supraglacial and 170 unconnected. They also documented that $0.3-2.0 \%$ of glacier ablation surfaces are covered by supraglacial lakes.

Imja Glacier is one of the largest debris-covered glaciers in the region, extending from an elevation of $\sim 5000$ to 7800 m a.s.l., with a mean elevation of 5877 m a.s.l. Nearly $80 \%$ of the glacier's surface area lies between 5000 and 6500 ma.s.l. (Fig. 1c). In 2011, the glacier had a mean surface gradient of $33^{\circ}$ and a mean snowline position at $5742 \mathrm{~m}$, and $27 \%$ of the glacier surface area was covered by debris (Thakuri and others, 2014). Imja Lake evolved near the glacier terminus $(\sim 5000$ m a.s.l.) during the 1960 s. The frontal ice of Imja Glacier is calving into Imja Lake and the lake is increasing in size (e.g. Fujita and others, 2009). According to Somos-Valenzuela and others (2014), the lake had a surface area of $1.257 \mathrm{~km}^{2}$ in 2012, and a sonar bathymetric survey in 2012 indicated a maximum depth of $116.3 \pm 5.2 \mathrm{~m}$ and an estimated volume of $(61.7 \pm 3.7) \times 10^{6} \mathrm{~m}^{3}$.
The climate of the Mount Everest region is dominated by the regional monsoon system. Imja Glacier is a summeraccumulation type glacier, and is primarily fed by the south Asian monsoon, whereas the winter precipitation from midlatitude westerly storms is minimal (Salerno and others, 2015). The prevailing atmospheric flow during the monsoon is south-north and southwest-northeast (e.g. Ichiyanagi and others, 2007). Observations from automatic weather stations (AWSs) at the Pyramid Observatory Laboratory $\left(27.96^{\circ} \mathrm{N}\right.$, $86.81^{\circ} \mathrm{E}$; $5050 \mathrm{ma.s.l}$.) from 1994 to 2013 indicate an annual mean temperature of $-2.4 \pm 0.5^{\circ} \mathrm{C}$ and a total annual precipitation (liquid and solid phase) of $449 \mathrm{~mm}$, with $\sim 90 \%$ of the annual precipitation falling during the summer months (June-September). The possible underestimation due to the limitations of the conventional heated tipping buckets used at the observatory, which may not fully capture the solid phase, is $\sim 3 \pm 1 \%$ of the total annual recorded precipitation (Salerno and others, 2015). The mean annual temperature decreases with increasing altitude $\left(0.6^{\circ} \mathrm{C}(100 \mathrm{~m})^{-1}\right)$, and the mean annual precipitation increases $\left(116 \mathrm{~mm}(100 \mathrm{~m})^{-1}\right)$ with altitude up to $\sim 2600 \mathrm{~m}$ and decreases above, along the Dudh Koshi river valley (Salerno and others, 2015).

\section{DATA}

Multitemporal satellite imagery from various sensors and topographic maps was used for assessing variations in glacier properties and lake surface area (Table 1). These data include: (1) a topographic map from 1963 (Thakuri and others, 2014); (2) all Landsat Enhanced Thematic Mapper Plus (ETM+) scenes dated 2001 and one scene per year from 2002 to 2012 (20 scenes) after the ablation season (October-December); and (3) Landsat 8 Operational Land Imager (OLI) scenes from 2014 (8 scenes), with no or minimum cloud cover. Changes in glacier area are based on datasets described in Thakuri and others (2014), updated to 2013 using Landsat 8 OLI data of 10 October 2013 (Table 1) for homogeneous comparison between the glacier, lakes and climate. Surface elevation changes are based on the multitemporal Advanced Spaceborne Thermal Emission and Reflection Radiometer Global Digital Elevation Model (ASTER GDEM) version 2, a product of the Ministry of Economy, Trade, and Industry (METI) of Japan and NASA. Climate data used by Salerno and others (2015) form the basis of the climate interpretation.

Freely available Landsat data (retrieved from https:// earthexplorer.usgs.gov) were used to estimate flow velocity for three periods: 1992-93, 2000-01 and 2013-14. We reinforced the velocity change results by way of a comparison with a previous study that used ASTER data (see Section 4.2.1).

\section{METHODS}

\subsection{Lake surface area}

To extract the lake outlines from the Landsat imagery, blue $(0.45-0.52 \mu \mathrm{m})$ and near-infrared (NIR; 0.77-0.90 $\mu \mathrm{m}$ ) wavelength bands were used to calculate a normalized difference water index (NDWI): NDWI $=[\mathrm{NIR}$-blue $] /$ [NIR + blue]. The method, originally proposed by McFeeters (1996) and successfully adapted to our region by Bolch and others (2008a), was applied using a manual post-correction for shadowed and ice areas. Lake boundaries were manually 

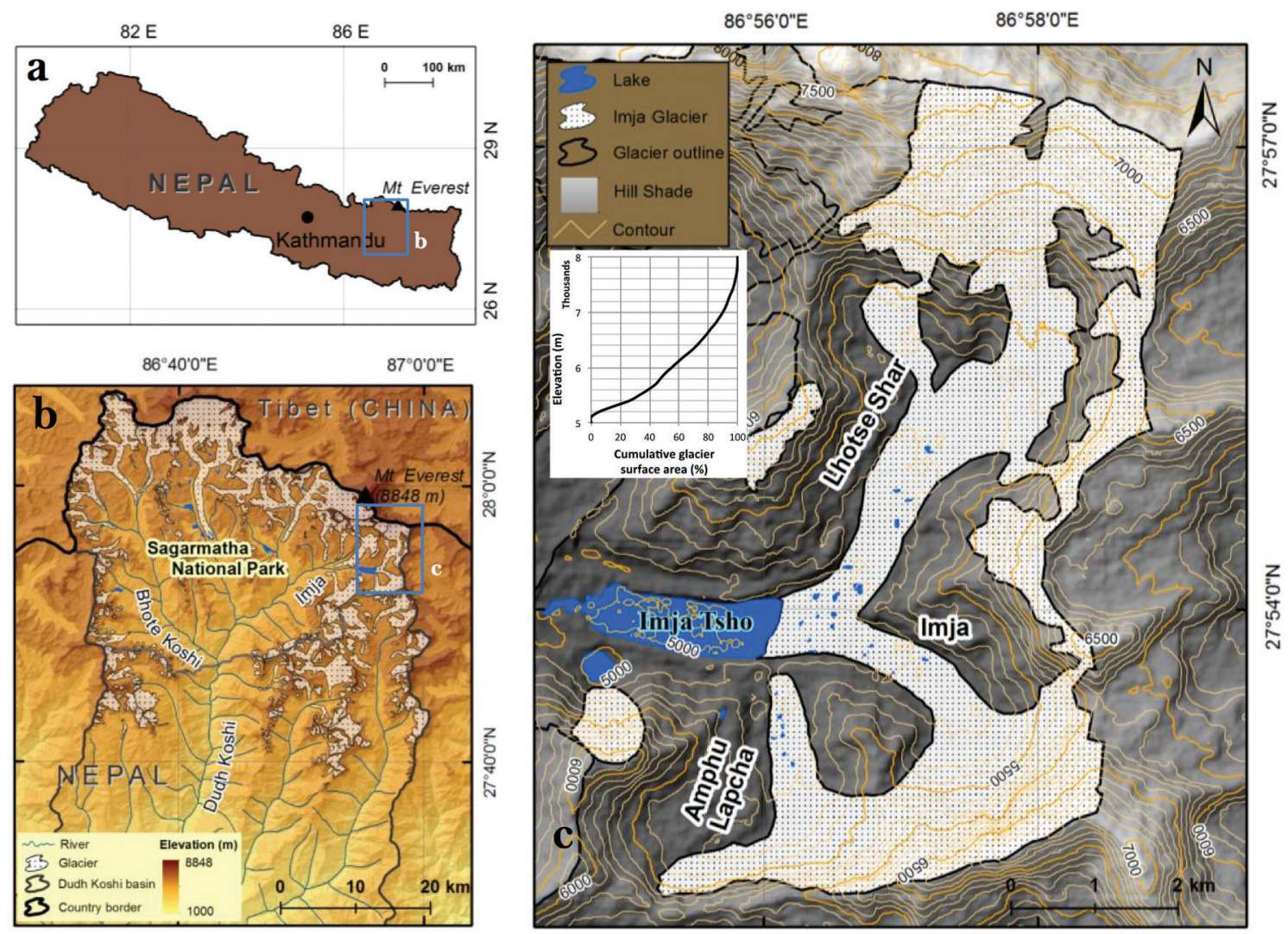

Fig. 1. Location of the reference study site in the map of (a) Nepal and (b) the Dudh Koshi river basin is marked by a rectangular box. (c) Detailed map of the site showing Imja Glacier and Lake(s) in 2013. Inset in (c) shows the surface area-elevation curve for Imja Glacier.

digitized from the topographic map and panchromatic Corona imagery.

The uncertainties in mapping a single glacial lake from an image were estimated as a product of the linear resolution error (LRE) and the perimeter ( $($ ) (Fujita and others, 2009; Salerno and others, 2012). As in these studies, we adopted 0.5 pixel for the LRE, assuming that on average the lake margin passes through the centres of pixels along its perimeter. The uncertainties in the changes in lake surface area ( $\Delta$ Surf) were derived using a standard error propagation rule: the root sum of the squares (rss, uncertainty = $\sqrt{e_{1}^{2}+e_{2}^{2}}$, where $e_{1}$ and $e_{2}$ are uncertainties from the first and second scenes) of the mapping uncertainty in a single scene. We did not consider the co-registration error because the comparison was not performed pixel by pixel.

\subsection{Glacier variables}

In this study, six glacier variables were analysed: surface area, terminus, snowline altitude (SLA), debris coverage, elevation change $(\Delta Z)$ and flow velocity $\left(V_{f}\right)$.

\subsubsection{Glacier surface area, terminus, SLA and debris coverage}

The dataset from Thakuri and others (2014) was used to study the glacier surface area change, terminus change, shift of SLA and debris-covered area change from 1962 to 2011. The analysis extended until 2013 using a new Landsat 8 OLI image from 10 October 2013 (Table 1). We followed the same procedure as described by Thakuri and others (2014) for calculating and evaluating the uncertainties of the analysed variables while extending the study time period.
A semi-automatic method was used for delineating glacier outlines from the satellite image that involved an automatic delineation of glacier boundaries and an extensive manual post-correction (Paul and others, 2004). For the terminus analysis, a band of stripes with an interval of $50 \mathrm{~m}$ between each stripe in the band was drawn parallel to the main flow direction of the glacier, and the terminus change was calculated as the difference between any two images in the average length of the intersection of the stripes with the glacier outlines (Koblet and others, 2010). Snowlines were derived manually from post-monsoon imagery (OctoberDecember). The snowlines on the glaciers were distinguished from the images as the boundary between the bright white snow and the darker ice by visual interpretation and using false-colour composite (FCC). The SLA was calculated as the average altitude of the identified snowline using the ASTER GDEM. A map-based SLA was used to support the snowline position derived from the 1962 Corona image (Thakuri and others, 2014). For delineating debris-covered area, we used the glacier outline map with the corresponding satellite image and the ASTER GDEM. The debriscovered area was delineated manually by identifying lateral and frontal moraine and further using the thermal band. The boundary between debris-free and debris-covered ice was identified as a line between the bright and darker ice area by visual interpretation and the FCC.

The uncertainties associated with the mapping of the glacier surface area and the debris-covered area were estimated as for the lake surface area, a product of the LRE and I (Salerno and others, 2012). The uncertainty in change of glacier surface and debris-covered area was derived using the rss. The measurement accuracy of the terminus position 
Table 1. Datasets used in the study

\begin{tabular}{|c|c|c|c|c|}
\hline Acquisition date & Mission/sensor & $\begin{array}{l}\text { Resolution } \\
\text { m }\end{array}$ & Scene ID & Application* \\
\hline 15 Dec 1962 & Corona $\mathrm{KH}-4$ & $\sim 8$ & DS009050054DA175_175 & Lake \\
\hline 20 Nov 1970 & Corona $\mathrm{KH}-4 \mathrm{~B}$ & $\sim 5$ & DS1112-1023DF157_157 & Lake \\
\hline 2 Nov 1975 & Landsat 4 MSS & 60 & LM21510411975306A- & Lake \\
\hline 17 Nov 1992 & Landsat 5 TM & 30 & LT51400411992322ISP00 & $V_{\mathrm{f}}$, Lake \\
\hline 30 Oct 2000 & Landsat 7 ETM+ & $15^{+}$ & LE71400412000304SGS00 & $V_{\mathrm{f}}$, Lake \\
\hline 17 Oct 2001 & Landsat 7 ETM+ & $15^{+}$ & LE71400412001290SGSO0 & $V_{\mathrm{f}}$ \\
\hline 10 Oct 2013 & Landsat $8 \mathrm{OLI}$ & $15^{+}$ & LC81400412013283LGN00 & $V_{f}$, Lake \\
\hline 22 May 2014 & Landsat $8 \mathrm{OLI}$ & $15^{+}$ & LC81400412014142LGN00 & Lake \\
\hline 30 Nov 2014 & Landsat $8 \mathrm{OLI}$ & $15^{+}$ & LC81400412014334LGN00 & $V_{f}$ \\
\hline 24 Oct 2008 & ALOS AVNIR 2 & 10 & ALAV2A14647304 & Lake \\
\hline 20 Dec 2001 & Terra ASTER & 15 & $\begin{array}{c}\text { AS- } \\
\text { T_L1- } \\
\text { A_00312202001050229_20- } \\
\text { 090617073207_20295 }\end{array}$ & $\Delta Z$ \\
\hline 6 Jan 2008 & Terra ASTER & 15 & $\begin{array}{c}\text { AS- } \\
\text { T_L1- } \\
\text { A_00301062008045936_20- } \\
\text { 090617065646_14098 }\end{array}$ & $\Delta Z$ \\
\hline 22 Nov 2014 & Terra ASTER & 15 & $\begin{array}{c}\text { AS- } \\
\text { T_L1- } \\
\text { A_00311222014045939_20- } \\
\text { 141210051220_17098 }\end{array}$ & $\Delta Z$ \\
\hline
\end{tabular}

${ }^{*} V_{\mathrm{f}}$ : glacier flow velocity; $\Delta Z$ : elevation change. ${ }^{\dagger}$ Panchromatic band and pan-sharpened image.

was estimated as the rss of the LRE and the referencing error (RE) (Hall and others, 2003). The elevation error associated with a shift of SLA was estimated as the rss between the pixel resolution combined with the mean surface slope (Pelto, $2011)$ and the vertical error of the GDEM (20 m).

\subsubsection{Glacier flow velocity $\left(V_{f}\right)$}

The velocities were derived from the image pairs by featuretracking of the glacier surface using the normalized crosscorrelation (NCC) algorithm in the Correlation Image Analysis Software (CIAS; Kääb and Vollmer, 2000). The NCC algorithm was selected from among several options for image correlation, none of which outperforms the others, because this is a simple and widely used algorithm for correlation of images that performs better on narrow glaciers (Heid and Kääb, 2012; Paul and others, 2015). The image pairs were co-registered before image correlation. The rootmean-square errors (RMSEx $y$ ) after the co-registration were 21.2, 12.8 and $4.9 \mathrm{~m}$ for 1992-93, 2000-01 and 2013-14, respectively. Potential outlier values higher than a $100 \mathrm{~m} \mathrm{a}^{-1}$ offset and maximum correlation coefficients lower than 0.6 were discarded. The gaps remaining after the removal of outliers were filled linearly by kriging.

The potential use of Landsat data for $V_{f}$ measurements has been demonstrated by previous studies (e.g. Kääb and others, 2005; Paul and others, 2015). Deriving velocities from Landsat imagery with $30 \mathrm{~m}$ (TM) and $15 \mathrm{~m}$ (ETM+ pan) spatial resolutions has certain limitations that need to be considered when interpreting the results. Paul and others (2015) asserted that the accuracy of measured $V_{f}$ using high to very high-resolution SAR data with a time interval of one satellite orbital cycle is $\sim 10 \mathrm{~m} \mathrm{a}^{-1}$, similar to the accuracy for medium-resolution optical satellite imagery (e.g. Landsat ETM+ pan), which is on the order of $15 \mathrm{~m} \mathrm{a}^{-1}$ for images acquired 1 year apart. Landsat data cover a wide spatial and temporal range and produce good results for rapidly flowing glaciers; however, their capacity to capture the $V_{f}$ of very slow-flowing glaciers can be limited by their resolution. Previous studies indicate that displacement values below 1 pixel have high uncertainty. In this study, the image coregistration errors (RMSEx $y$ ) that were calculated after the co-registration of image pairs for measuring $V_{f}$ did not exceed 1 pixel. Thus we adopted a mean uncertainty of 1 pixel size.

\subsubsection{Glacier elevation change $(\Delta Z)$}

The digital elevation model (DEM) differencing method was used to compute the glacier $\Delta Z$ from the multispectral Terra ASTER images (Paul and Haeberli, 2008; Bolch and others, 2011). The ASTER sensor has four visible/near-infrared (VNIR; $15 \mathrm{~m}$ resolution) bands, including a backwardlooking band (3B) that has stereoscopic viewing capabilities for generating DEMs (Kamp and others, 2005; Toutin, 2008). We generated $30 \mathrm{~m}$ DEMs for 2001, 2008 and 2014 from the cloud-free ASTER stereo bands, nadir $(3 \mathrm{~N})$ and backward-looking (3B) data. For co-registration of the ASTER stereo bands, $\sim 25$ ground-control points (GCPs) were assigned to identifiable objects (e.g. mountain peaks, river crossings, rocks) in the Landsat OLI from 2013. The elevation information was obtained from the ASTER GDEM. The co-registration model was accepted when the RMSEs of GCPs were less than 1 pixel $(15 \mathrm{~m})$, and the enhanced Automated Terrain Extractor (eATE) function in the Leica Photogrammetric Suite (LPS) of Earth Resource Data Analysis System (ERDAS) Imagine software was applied.

Elevation changes for 2001-08 and 2001-14 were calculated using 2001 as the reference DEM. The DEMs were co-registered using the method of Nuth and Kääb (2011) to ensure the comparability and quality of the DEMs. We applied the computed horizontal and vertical (i.e. 
Table 2. Data on surface area, terminus, snowline altitude (SLA), debris-covered area and morphological parameters for Imja Glacier and lakes during 1962-2013

\begin{tabular}{|c|c|c|c|c|c|c|c|}
\hline Variable/parameter & 1962 & 1975 & 1992 & 2000 & 2008 & 2011 & 2013 \\
\hline \multicolumn{8}{|l|}{ Imja Lake } \\
\hline Surface area $\left(\mathrm{km}^{2}\right)$ & $0.03 \pm 0.01$ & $0.14 \pm 0.02$ & $0.70 \pm 0.03$ & $0.84 \pm 0.04$ & $1.01 \pm 0.05$ & $1.24 \pm 0.05$ & $1.35 \pm 0.05$ \\
\hline Perimeter (km) & 2.605 & 2.533 & 3.888 & 4.793 & 4.829 & 5.939 & 6.866 \\
\hline \multicolumn{8}{|l|}{ Supraglacial lakes } \\
\hline Surface area $\left(\mathrm{km}^{2}\right)$ & $0.037 \pm 0.014$ & - & $0.077 \pm 0.038$ & $0.065 \pm 0.029$ & $0.066 \pm 0.024$ & $0.082 \pm 0.045$ & $0.102 \pm 0.045$ \\
\hline Number & 8 & - & 16 & 23 & 24 & 25 & 25 \\
\hline \multicolumn{8}{|l|}{ Imja Glacier } \\
\hline Surface area $\left(\mathrm{km}^{2}\right)$ & $28.1 \pm 0.5$ & $28.0 \pm 2.2$ & $27.0 \pm 0.8$ & $27.2 \pm 0.6$ & $26.4 \pm 0.4$ & $25.5 \pm 0.6$ & $24.7 \pm 0.6$ \\
\hline Terminus change $(\mathrm{m})$ & 0 & $-862 \pm 30$ & $-1320 \pm 11$ & $-1656 \pm 9$ & $-1911 \pm 6$ & $-2118 \pm 9$ & $-2256 \pm 9$ \\
\hline $\mathrm{SLA}(\mathrm{m})$ & $5340 \pm 20$ & $5480 \pm 35$ & $5655 \pm 25$ & $5673 \pm 21$ & $5691 \pm 21$ & $5742 \pm 21$ & $5796 \pm 21$ \\
\hline Debris-covered area $\left(\mathrm{km}^{2}\right)^{*}$ & $5.59 \pm 0.09$ & $5.11 \pm 0.41$ & $5.53 \pm 0.16$ & $5.71 \pm 0.12$ & $6.28 \pm 0.09$ & $6.65 \pm 0.15$ & $6.93 \pm 0.16$ \\
\hline Slope $\left(^{\circ}\right)$ & 30 & 33 & 32 & 33 & 33 & 33 & 33 \\
\hline Aspect $\left(^{\circ}\right)$ & 210 & 204 & 210 & 212 & 215 & 218 & 218 \\
\hline Max elevation (m) & 7971 & 8226 & 8226 & 7803 & 7803 & 7803 & 7808 \\
\hline Mean elevation (m) & 5768 & 5807 & 5833 & 5844 & 5877 & 5877 & 5898 \\
\hline
\end{tabular}

*Debris-covered area was calculated by excluding common (2013 Imja Lake) glacier surface area impacted by Imja Lake growth in all years.

RMSEx $y, z)$ shift to the 2008 and 2014 DEMs. We discarded elevation differences exceeding $7.5 \mathrm{ma}^{-1}$ (greater than $3 \sigma$ of the mean elevation change) as possible outliers (Nuth and Kääb, 2011; Nuimura and others, 2012). The remaining gaps were filled linearly by kriging. Due to partial coverage of Imja Glacier in the 2014 ASTER scene, we were able to compare the elevation change only in the lower ablation portion of the glacier (see Fig. 7 further below). To ensure the homogeneous comparison and to detect the elevation change signal between periods, the mean elevation change was calculated only over the common area shared by all three DEMs (i.e. excluding both calved portions of the terminus and missing parts of the 2014 DEM).

The measurement uncertainties in $\Delta Z$ were estimated using the normalized median absolute deviation (NMAD; Höhle and Höhle, 2009) derived from a sample of terrain outside the glacier. NMAD is a robust method of estimating uncertainties and is considered to be less sensitive to outliers than the standard deviation or RMSE method. It was calculated using $\mathrm{NMAD}=1.4826 \times\left(\left|\Delta h_{i}-m_{\Delta h}\right|\right)$, where $\Delta h_{i}$ represents the individual errors $i=1,2, \ldots, n ; m_{\Delta h}$ is the median of the errors; and median $_{i}$ is the overall median for $i$ data points.

The estimated NMADs were $4.4 \mathrm{~m}$ for the $\Delta Z$ between 2001 and 2008 and $9.2 \mathrm{~m}$ for 2001 and 2014.

\section{RESULTS}

\subsection{Lake evolution}

5.1.1. Interannual variation of Imja Lake

Table 2 and Figures 2 and 3 present variations of Imja Lake from 1962 to 2013. Imja Lake appeared in the 1960s as small ponds (Fig. 2b). The lake surface measured $0.03 \pm 0.01 \mathrm{~km}^{2}$ in 1962 and grew to $1.35 \pm 0.05 \mathrm{~km}^{2}$ in 2013 (Fig. 3a) at a rate of $0.026 \pm 0.001 \mathrm{~km}^{2} \mathrm{a}^{-1}$. Imja Lake grew rapidly after 2008 (Fig. 3a). Based on a sonar bathymetric survey, Somos-Valenzuela and others (2014) reported that Imja Lake increased in depth from 90.5 to $116.3 \pm 5.2 \mathrm{~m}$ and in volume from $35.8 \pm 0.7 \times 10^{6}$ to $61.7 \pm 3.7 \times 10^{6} \mathrm{~m}^{3}$ during 2002-12. They also reported a surface area expansion rate of $0.039 \mathrm{~km}^{2} \mathrm{a}^{-1}$ during 200212 , whereas during the same period we observed a rate of $0.030 \pm 0.001 \mathrm{~km}^{2} \mathrm{a}^{-1}$.

\subsubsection{Intra-annual variation of Imja Lake}

Figures $4 \mathrm{a}$ and 5 present the intra-annual variations in Imja Lake surface area. We focused on 2001 (Fig. 4a) due to the availability of good-quality images spanning all seasons of that year, and we repeated the analysis with available data from 2014. The lake surface area decreases from a winter maximum to a minimum in May, prior to monsoon onset. The lake area then grows rapidly, and in 2 months reaches a maximum again that is sustained until winter. The lake surface area can be considered constant from July to January. Therefore, the interannual trend shown in Figure $3 \mathrm{a}$ is not significantly affected by the intra-annual variability inevitably introduced in the analysis; the satellite images are from a post-monsoon period when the lake surface, as we observed, is constant.

We developed possible interpretations of the observed surface variations. The decrease in surface area from January to May is likely due to the low input to the lake in the form of precipitation and glacier melting (temperatures are low during these months) (Fig. 4b). During the monsoon months (June-September), both precipitation and glacial melt (high temperatures) contribute to the increasing lake surface area. The more interesting aspect of the intra-annual trend of Imja Lake is the constant lake water level from July to December. Both temperature and precipitation start decreasing at the beginning of autumn, yet the water level remains constant. The smaller meteoric contribution is not questionable as the monsoon precipitation period is over. Groundwater inputs can be high after the monsoon; the water stored subglacially and englacially may be released to the lake over a period of a few weeks to months. However, evaporation from the lake surface might increase as air temperatures decrease, which results in a more negative moisture gradient between the lake surface and the air above. The sustained maximum in lake surface area during the post-monsoon and early winter requires further investigation. 

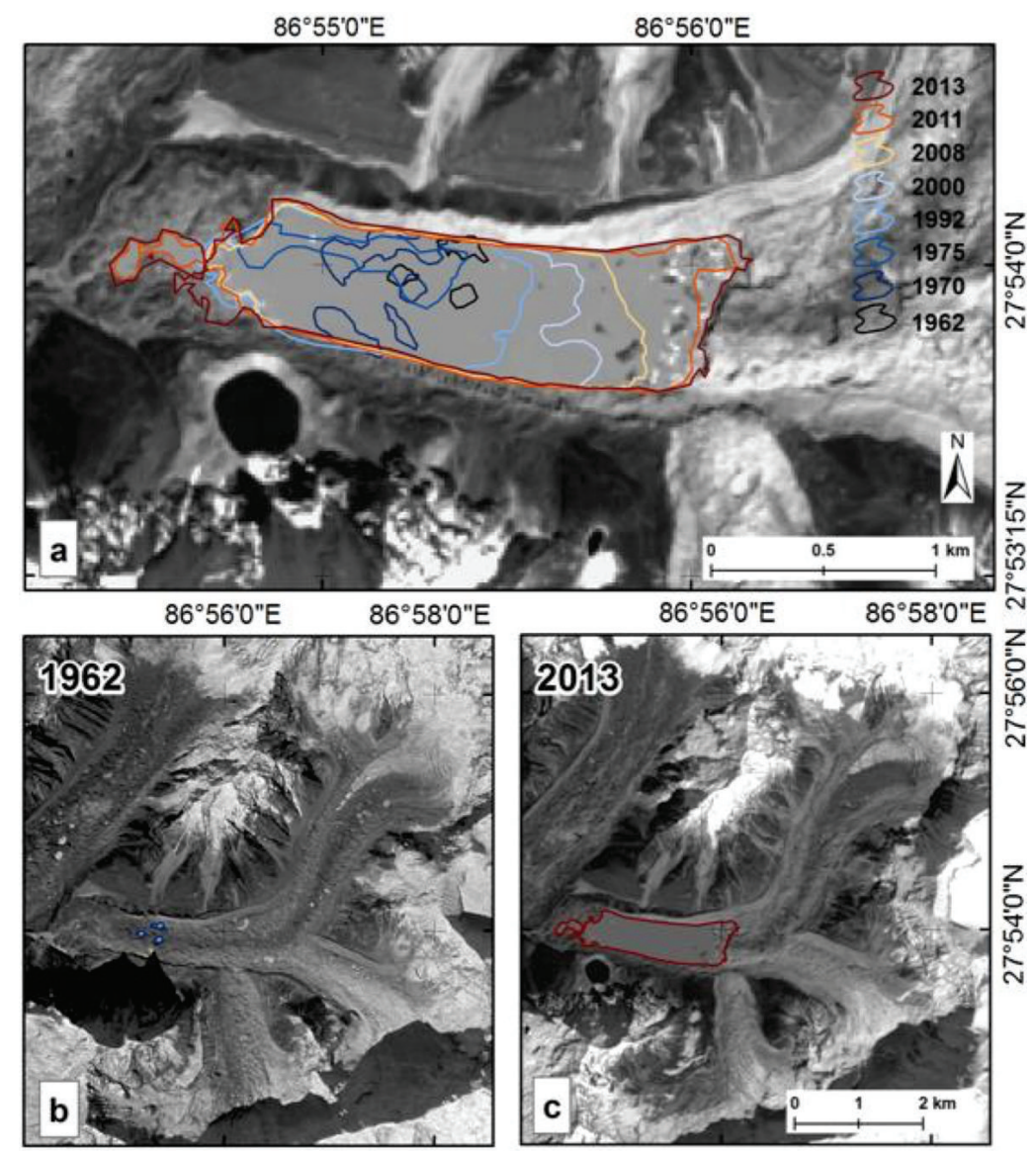

Fig. 2. Evolution of Imja Lake. (a) Temporal variation of surface area from 1962 to 2013. Background: (a) Landsat 8 OLI image acquired on 10 October 2013; (b) Corona KH-4 scene from 2 December 1962; and (c) Landsat scene from 2013 showing Imja Glacier and Lake.

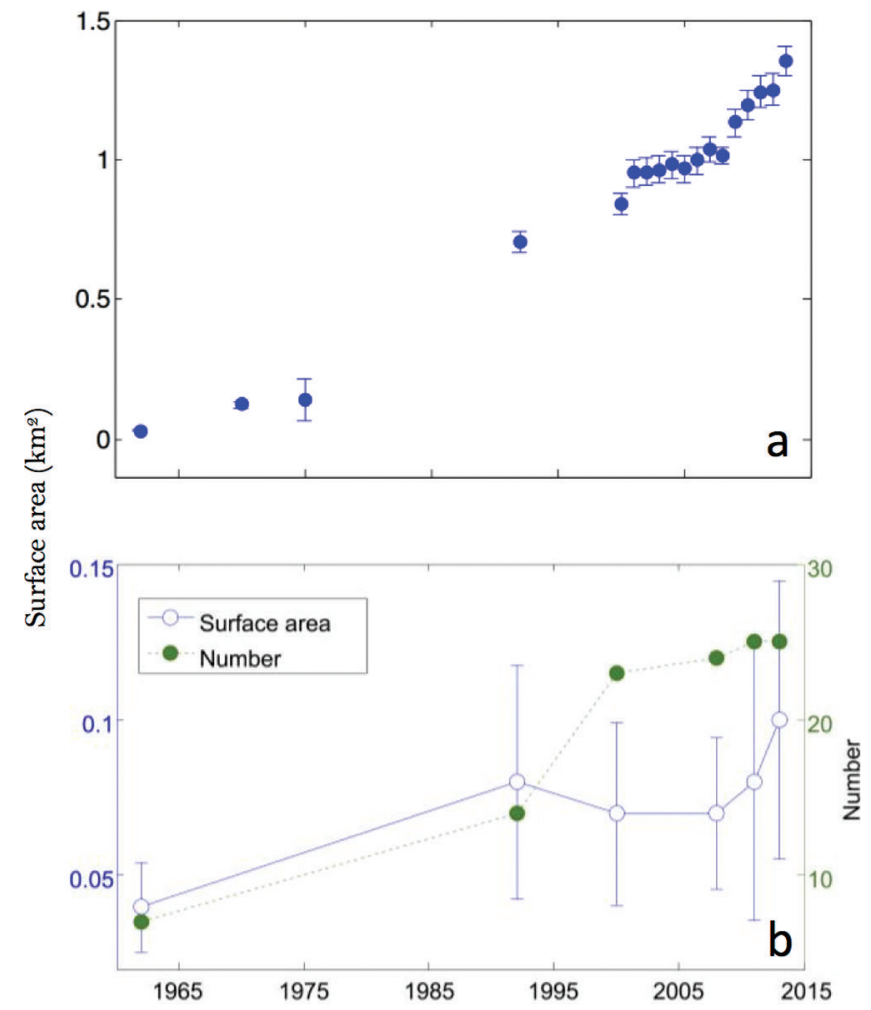

Fig. 3. Lake surface area change ( $\Delta$ Surf). (a) $\Delta$ Surf for Imja Lake ( $\sim 5000$ ma.s.l.) from 1962 to 2013; (b) number and surface area variation of the supraglacial lakes present on Imja Glacier. Note the different scales on the vertical axes in (a) and (b).

\subsubsection{Variations in supraglacial lakes}

Imja Glacier has several supraglacial lakes (ponds). We found 25 supraglacial lakes (all below elevation $5210 \mathrm{~m}$ where the surface slope is $\sim 10^{\circ}$ ), with a total area of $0.102 \pm 0.045 \mathrm{~km}^{2}$ in 2013 , and eight lakes in the early $1960 \mathrm{~s}$, with a total area of $0.037 \pm 0.014 \mathrm{~km}^{2}$. The number and size of lakes were approximately three times greater in 2013 than in the 1960s. However, due to their very small sizes, the associated uncertainties in the surface areas are large (Fig. 3b). Such supraglacial lakes are ephemeral and very unstable in space and time because they can drain suddenly when they connect with the subglacial drainage system (Benn and others, 2001).

\subsection{Glacier variations}

5.2.1. Glacier surface area, terminus, SLA and debris coverage variation

The surface area of Imja Glacier decreased from $28.1 \pm 0.5 \mathrm{~km}^{2}$ (1962) to $24.7 \pm 0.6 \mathrm{~km}^{2}$ (2013) at a mean rate of $-0.067 \pm 0.014 \mathrm{~km}^{2} \mathrm{a}^{-1}\left(-0.24 \% \mathrm{a}^{-1}\right)$ (Fig. 6; Table 2). Previous studies (Bolch and others, 2008b; Thakuri and others, 2014) indicated accelerated glacier shrinkage after the 1990s in the Everest region. We found that Imja Glacier experienced a loss of $0.04 \pm 0.03 \mathrm{~km}^{2} \mathrm{a}^{-1}$ from 1962 to 1992 and $0.11 \pm 0.05 \mathrm{~km}^{2} \mathrm{a}^{-1}$ from 1992 to 2013; the loss rate during the latter period was nearly three times that of the former and is in agreement with previous studies.

The terminus of Imja Glacier retreated $2256 \pm 9 \mathrm{~m}$ $\left(\sim 44 \mathrm{~m} \mathrm{a}^{-1}\right)$ from 1962 to 2013 (Table 2). This rate of change is the greatest within the SNP (Thakuri and others, 

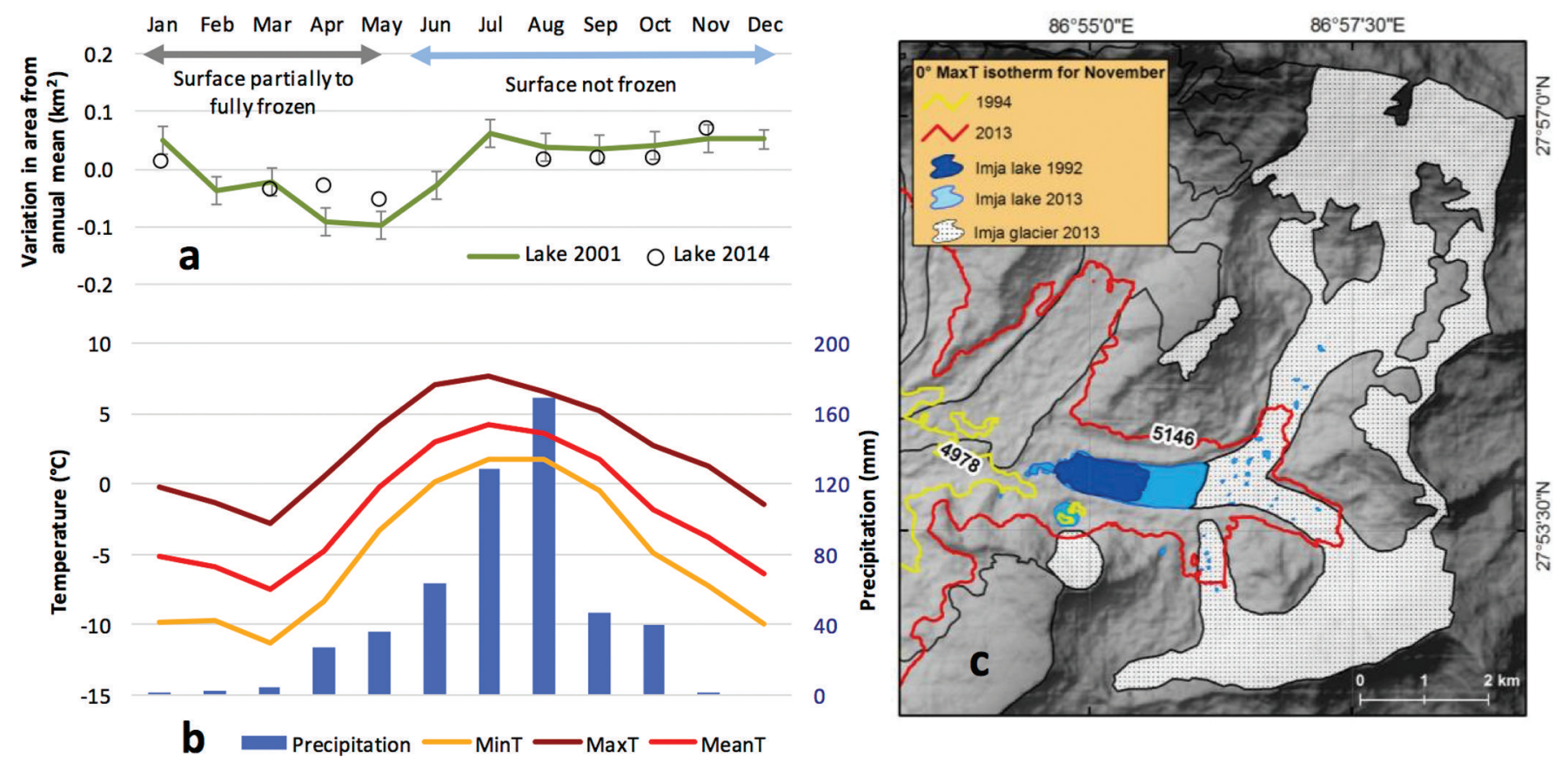

Fig. 4. Lake surface area variation and local meteorological data. (a) Intra-annual surface area variation of Imja Lake. The green line represents the surface anomaly (difference from mean; $\mathrm{km}^{2}$ ) for 2001 and black circles for 2014. Vertical bars represent uncertainty of measurement as described in the methods. (b) Variations of monthly minimum temperature (MinT), maximum temperature (MaxT), mean temperature (MeanT) and precipitation in 2001 from Pyramid station (5050 ma.s.l.). (c) $0^{\circ} \mathrm{C}$ isotherms of November MaxT for 1994 and 2013. The lake distributions are indicated.

2014). This retreat could be attributed to the presence of the proglacial Imja Lake, which enhances glacier melt and favours mass loss due to calving. Greater retreat of debriscovered glaciers with proglacial lakes compared with those without proglacial lakes has also been found in the Sikkim Himalaya (Basnett and others, 2013). Furthermore, the SLA on Imja Glacier shifted upward by $456 \pm 30 \mathrm{~m}$ (mean $\sim 9 \mathrm{~m} \mathrm{a}^{-1}$ ) from $5340 \pm 20$ to $5796 \pm 21 \mathrm{~m}$ between 1962 and 2013 (Fig. 6b). This SLA shift is comparable with the shift on large glaciers reported by Thakuri and others (2014) (e.g. $7 \mathrm{ma}^{-1}$ on Khumbu; $8 \mathrm{ma}^{-1}$ on Bhote Koshi). The increased SLA, while subject to uncertainty given our use of only one scene per year and the timing of the maximum SLA, is comparable with SLA and glacier albedo trends observed in the region (Thakuri and others, 2014; Brun and others, 2015). The upward shift of the SLA indicates a clear negative trend in the mass balance. Figure $6 \mathrm{c}$ and Table 2 show an increase in debris-covered area from $5.59 \pm 0.09$ to $6.93 \pm 0.16 \mathrm{~km}^{2}$ (mean $0.026 \pm 0.004 \mathrm{~km}^{2} \mathrm{a}^{-1}$ ) between
1962 and 2013. This value was estimated without considering the common glacier surface area (2013) impacted by the evolution of the lake in all years.

Figure $6 \mathrm{~d}$ presents $\Delta$ Surf by elevation for the glacier during two periods: 1962-92 and 1992-2013. A comparison of these values indicates an opposite trend: during 1962-92, the main area of surface shrinkage is below an elevation of $5750 \mathrm{~m}$, whereas surface area increased at higher elevations. During 1992-2013, a clear decrease in glacier surface area was observed at even higher elevations (up to $6200 \mathrm{~m}$ ). Such different behaviours are a response to climate, as discussed in Section 6.2.

\subsubsection{Glacier elevation change $(\Delta Z)$}

The surveyed part of Imja Glacier experienced a mean $\Delta Z$ of $-1.29 \pm 0.71 \mathrm{~m} \mathrm{a}^{-1}$ during 2001-14 compared with $-1.06 \pm 0.63 \mathrm{~m} \mathrm{a}^{-1}$ during 2001-08, indicating an increasingly negative rate $\left(-1.56 \pm 0.80 \mathrm{ma}^{-1}\right)$ during $2008-14$. However, the difference is not significant given the high
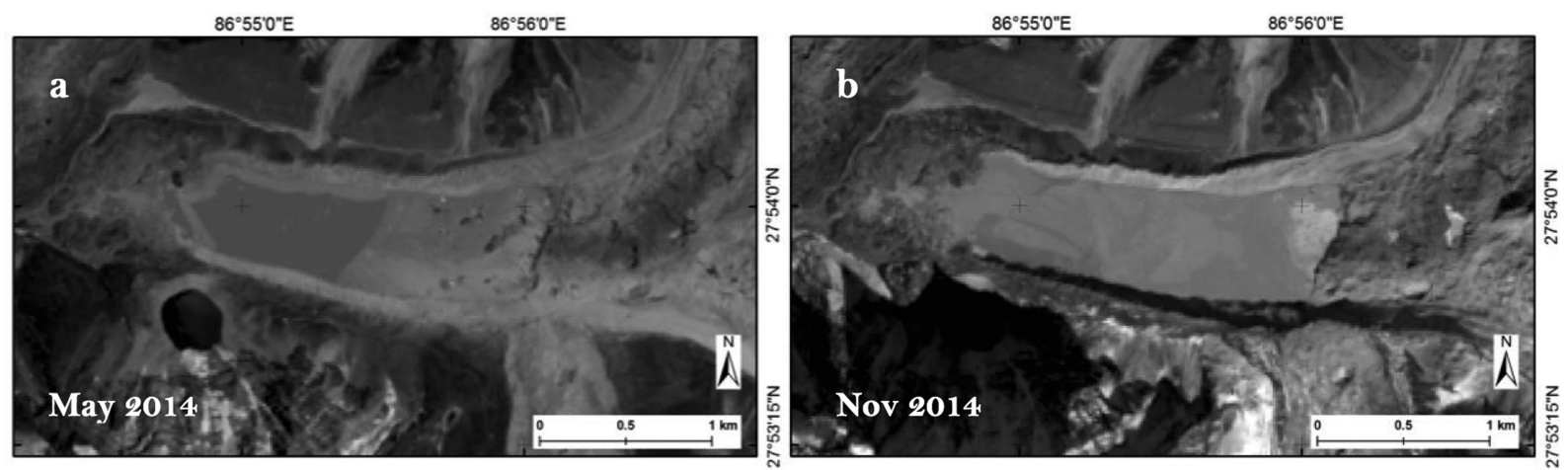

Fig. 5. Imja Lake (a) as seen in the Landsat 8 OLI image acquired in May 2014, indicating partially frozen and reduced lake surface area, and (b) in November 2014. 

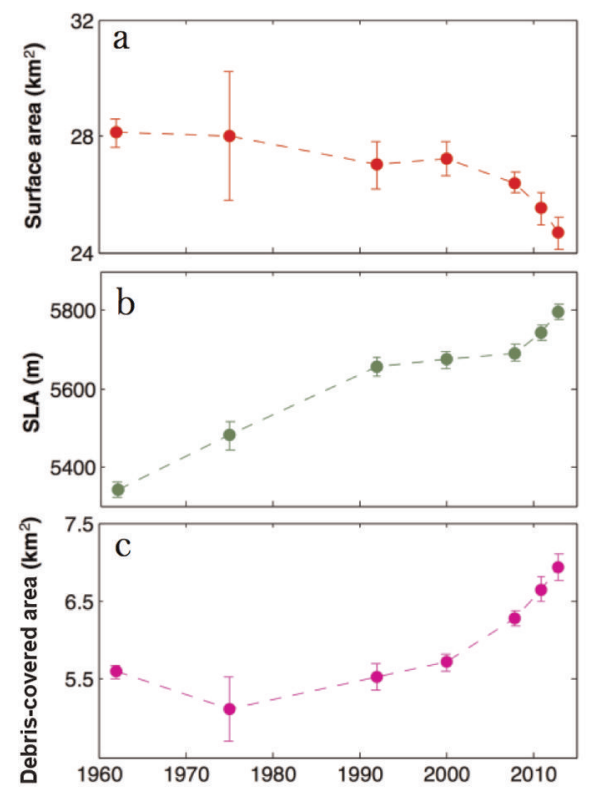

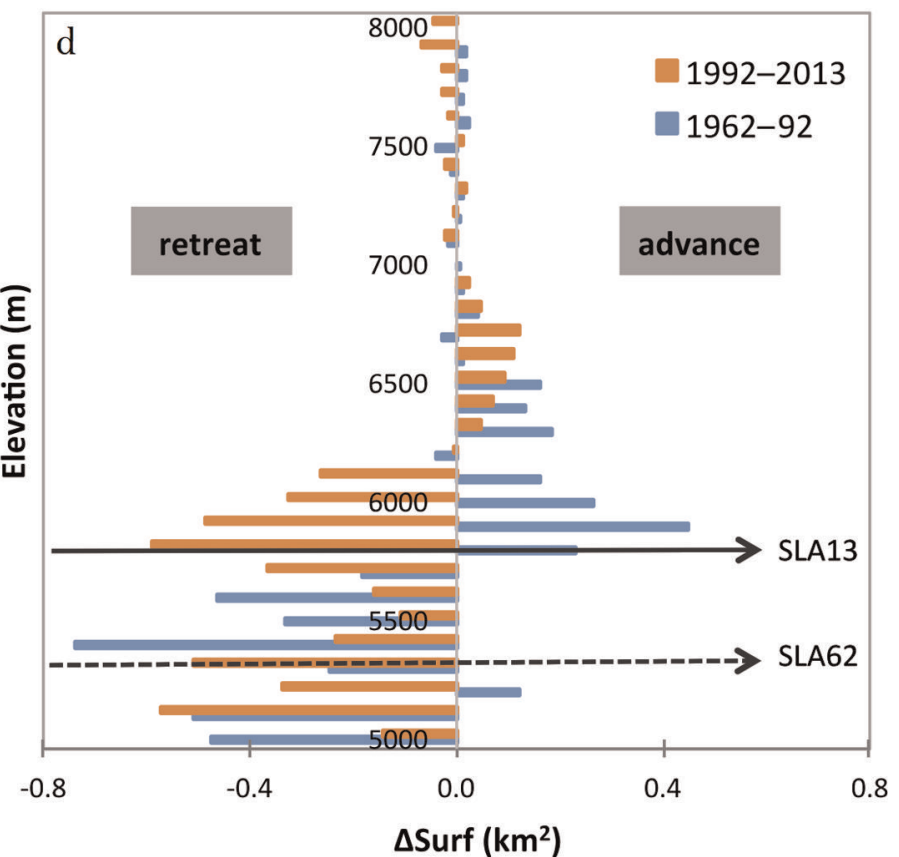

Fig. 6. Changes in Imja Glacier variables between 1962 and 2013: (a) surface area, (b) snowline altitude (SLA) and (c) debris-covered area. Points and vertical bars represent observations and associated uncertainties, respectively. (d) The glacier surface area change ( $\Delta$ Surf) by elevation in the periods 1962-92 and 1992-2013; the SLA positions are indicated for 1962 (SLA62) and 2013 (SLA13).

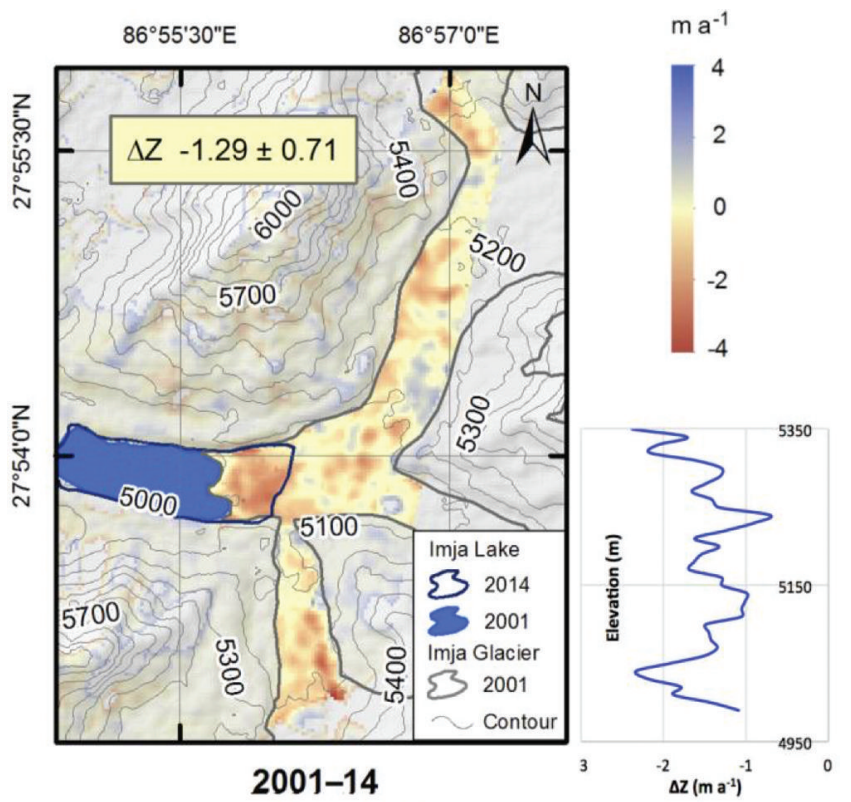

Fig. 7. Glacier elevation change $(\Delta Z)$ of Imja Glacier for 2001-14, with the area mean (inset box). Mean $\Delta Z$ is plotted as a function of elevation in the panel on the right. uncertainty (Fig. 7; Table 3). Between 2001 and 2014, the terminus of Imja Glacier (up to an elevation of $5085 \mathrm{~m}$ ) experienced a more negative $\Delta Z$ than the remainder of the area covered by the ASTER imagery $(-2.30 \pm 0.71$ versus $-1.29 \pm 0.71 \mathrm{~m} \mathrm{a}^{-1}$ ) due to calving and subsequent expansion of the lake. Elsewhere, elevation loss atypically increases up-glacier (Fig. 7) due to decreasing debris thickness upslope (Rounce and McKinney, 2014).

While calculating the $\Delta Z$ of Imja Glacier during 200108, we simultaneously considered other glaciers in the SNP and found that these glaciers $\left(102.5 \mathrm{~km}^{2}\right)$ experienced an overall $\Delta Z$ of $-0.66 \pm 0.63 \mathrm{~m} \mathrm{a}^{-1}$. The estimated $\Delta Z$ during $2001-08$ is comparable with previous findings (Table 3 ). We found a mass loss of $-0.62 \pm 0.68 \mathrm{mw}$.e. $\mathrm{a}^{-1}$ for 2001-08 based on the same set of glaciers (using the ice density of $850 \pm 60 \mathrm{~kg} \mathrm{~m}^{-3}$ suggested by Huss, 2013). Furthermore, three previous studies (Table 3) reported that Imja Glacier experienced the greatest mass loss (Imja-Lhotse Shar; table 5 of Gardelle and others (2013) and Table 3 in this study). Bolch and others (2011) and Nuimura and others (2012) further confirmed an accelerated rate of mass loss during 2000-08 compared with the previous period, and suggested that glaciers connected to a glacial lake at their terminus experienced greater surface lowering.

Table 3. Glacier elevation change $(\Delta Z)$ and mass change $(\Delta m)$

\begin{tabular}{lcccc}
\hline & Period & Imja Glacier & Ten common glaciers* & Source \\
\hline$\Delta Z\left(\mathrm{~m} \mathrm{a}^{-1}\right)$ & $2008-14$ & $-1.56 \pm 0.80$ & - & This study \\
& $2001-14$ & $-1.29 \pm 0.71$ & - & \\
& $2001-08$ & $-1.06 \pm 0.63$ & $-0.73 \pm 0.63$ & Bolch and others (2011) \\
& $2002-07$ & $-1.45 \pm 0.52$ & $-0.79 \pm 0.52$ & Nuimura and others (2012) \\
& $2000-08$ & $-0.93 \pm 0.60$ & $-0.45 \pm 0.60$ & Gardelle and others (2013) \\
& $1999-2011$ & $-0.70 \pm 0.52$ & $-0.41 \pm 0.21$ & $\left.\mathrm{a}^{-1}\right)$ \\
& & & &
\end{tabular}

*In the south of Mount Everest as in Bolch and others (2011). 

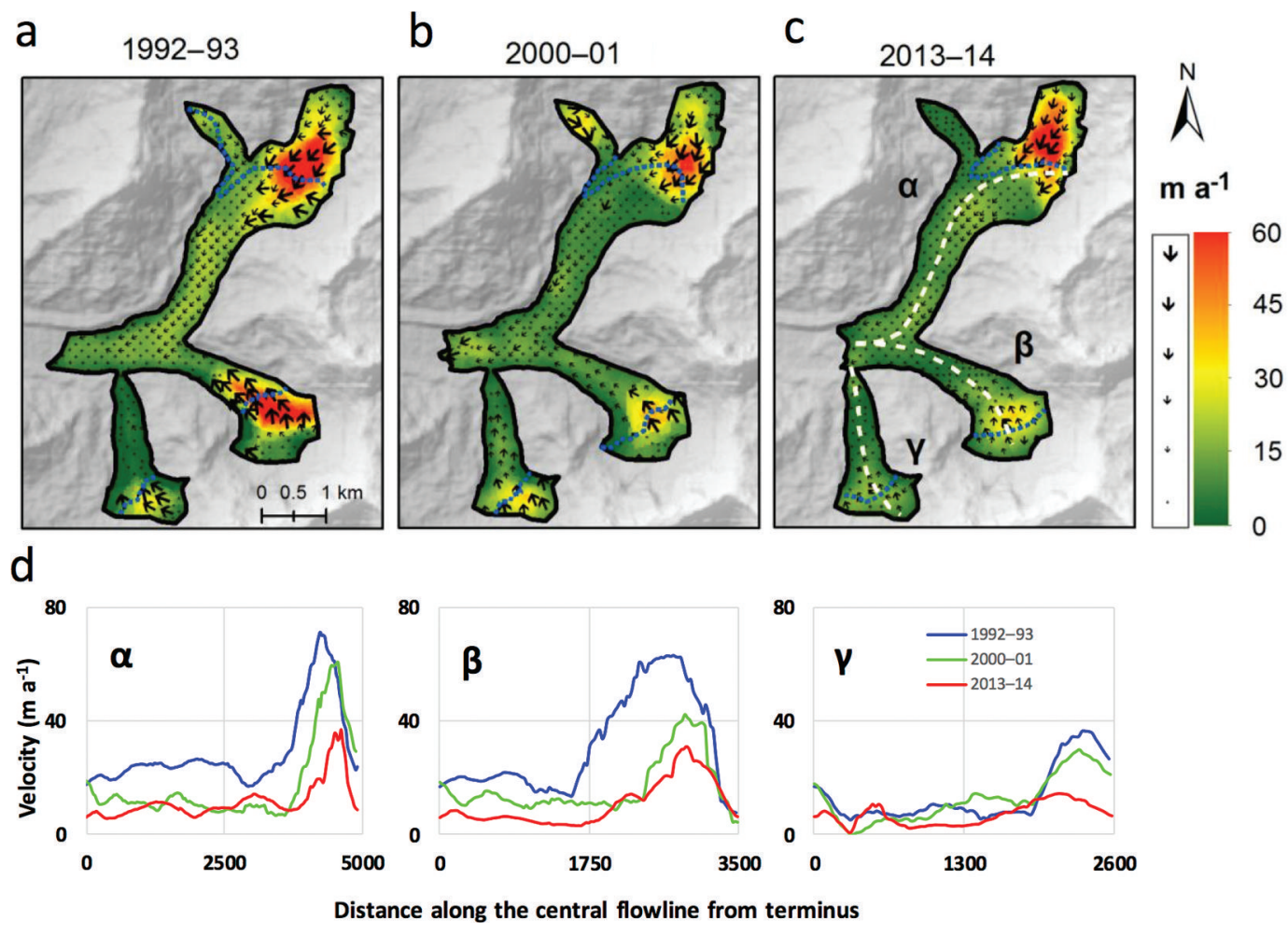

Fig. 8. Changes in glacier flow velocity $\left(V_{\mathrm{f}}\right)$. $(\mathrm{a}-\mathrm{c}) V_{\mathrm{f}}$ of glaciers at three periods between the $1990 \mathrm{~s}$ and 2014 . The estimated positions of the transition zone between debris-covered and debris-free glacier parts are indicated by dotted blue lines. In (c) the central flow paths of the glaciers at three branches are annotated as $\alpha, \beta$ and $\gamma$. (d) $V_{\mathrm{f}}$ profiles along the glacier central flowlines ( $\alpha$ : Lhotse Shar; $\beta$ : Imja; $\gamma$ : Amphu Lapcha).

\subsubsection{Glacier flow velocity $\left(V_{\mathrm{f}}\right)$}

Figure 8 and Table 4 present the flow velocity of Imja Glacier during three measurement periods. The trend suggests an overall decrease in $V_{f}$ over time. The glacierwide mean $V_{\mathrm{f}}$ was $37 \pm 30 \mathrm{ma}^{-1}$ during 1992-93, $31 \pm$ $15 \mathrm{~m} \mathrm{a}^{-1}$ during 2000-01 and $23 \pm 15 \mathrm{ma}^{-1}$ during 201314 . When comparing the velocity profiles along the central flowline (Fig. 8c) in each branch of the glacier $(\alpha, \beta$ or $\gamma)$ during each period (Fig. 8d), in addition to the overall decrease in $V_{\mathrm{f}}$, we observed lower values of $V_{\mathrm{f}}$ toward the terminus and higher values upslope on the glacier.

The transition zone between debris-covered and debrisfree parts of the glacier exhibits higher flow velocities (Fig. 8a), whereas areas near Imja Lake exhibit lower velocities. During 1992-93, $V_{f}$ was $34 \pm 30$ and $57 \pm$ $15 \mathrm{~m} \mathrm{a}^{-1}$ in the debris-covered and upper debris-free areas, respectively, whereas during 2013-14 these respective values were $15 \pm 15$ and $37 \pm 15 \mathrm{~m} \mathrm{a}^{-1}$ (Table 4). Considering the uncertainties in the measurements reported above

Table 4. Flow velocity $\left(V_{\mathrm{f}}\right)$ of Imja Glacier

Computed $V_{f}$ for

\begin{tabular}{lcccc} 
Period & $\begin{array}{c}\text { Debris-covered } \\
\text { area } \\
\mathrm{m} \mathrm{a}^{-1}\end{array}$ & $\begin{array}{c}\text { Debris-free } \\
\text { area } \\
\mathrm{m} \mathrm{a}^{-1}\end{array}$ & $\begin{array}{c}\text { Glacier-wide } \\
\text { mean } \\
\mathrm{m} \mathrm{a}^{-1}\end{array}$ & $\mathrm{~m} \mathrm{a}^{-1}$ \\
\hline $1992-93$ & 34 & 57 & 37 & \pm 30 \\
$2000-01$ & 22 & 45 & 31 & \pm 15 \\
$2013-14$ & 15 & 37 & 23 & \pm 15 \\
\hline
\end{tabular}

(ranging from 15 to $30 \mathrm{~m} \mathrm{a}^{-1}$ ), we assert that the $V_{\mathrm{f}}$ was very low to zero in the lower parts of the glacier. However, the more striking differences were on the debris-free part of the glacier, where a decreasing $V_{\mathrm{f}}$ was apparently observed. The $V_{f}$ decreased by 35\% during 2013-14 compared with 199293. This finding confirms a general decrease in $V_{f}$ in recent years. Furthermore, the glacier experienced a greater decrease in $V_{f}$ where more negative values of $\Delta Z$ were observed during 2001-14, indicating that the decrease in $V_{\mathrm{f}}$ may have been induced by a more negative glacier mass balance (Figs 7 and 8).

Few investigators have studied $V_{\mathrm{f}}$ in the region, and most have focused only on Khumbu Glacier (Müller, 1968; Kodama and Mae, 1976; Seko and others, 1998; Nakawo and others, 1999; Luckman and others, 2007). Quincey and others (2007), based on interferometic synthetic aperture radar (InSAR) data from 29 to 30 March 1996, estimated an annual velocity of $\sim 18 \mathrm{~m}$ for the Lhotse Shar $(\alpha)$ branch. This is lower than the values we observed for 1992-93 and 2000-01. As discussed by Willis (1995), $V_{f}$ varies during the year as a result of various factors. Our results are consistent with those of Bolch and others (2008a), who showed using ASTER data that velocities of $>40 \mathrm{~m} \mathrm{a}^{-1}$ can be observed on the upper part of the Lhotse-Shar branch of Imja Glacier, and found significantly lower velocities downslope toward the terminus during 2000-03.

\section{DISCUSSION}

\subsection{Boundary conditions for evolution of lakes}

Glacier surface gradient is an important control on glacier velocity and the evolution of supraglacial lakes (Quincey 
and others, 2009; Sakai and Fujita, 2010; Salerno and others, 2012). Previous studies (Reynolds, 2000; Quincey and others, 2007; Röhl, 2008; Sakai and Fujita, 2010) demonstrated that in various parts of the world large glacial lakes can form on glaciers the surface gradient of which before lake formation was $<2^{\circ}$. Reynolds (2000) reported that isolated small ponds in the Bhutanese Himalaya might form where the glacier's slope is $6-10^{\circ}$. A glacial lake can develop due to low flow rates at high elevations and stagnant areas around the glacier's terminus (Quincey and others, 2009). Lower gradients correspond to lower gravitational driving stresses that, by decreasing the glacier's flow, allow for the development of stagnant ice (Scherler and others, 2011), which is favourable for the formation of supraglacial lakes.

Salerno and others (2012) demonstrated that the slopes of upstream and downstream areas of the glacier favour supraglacial lake formation. The slope of the glacier upstream affects both the low flow velocity and the high ablation rates at the glacier terminus. Furthermore, the imbalance between the two glacier zones generates the downslope movement of debris, snow and ice. Salerno and others (2012) found that the gradient of the glacier upstream is inversely correlated with the total surface area of the lakes downstream. We observed a slope of $13^{\circ}$ in the debriscovered (downstream) portion of Imja Glacier and a gradient of $37^{\circ}$ in the upstream portion. Both of these gradients are equal to the mean values for 28 other glaciers located in the SNP $\left(13^{\circ}\right.$ in downstream portions and $38^{\circ}$ in upstream portions). Consequently, Salerno and others (2012) observed on Imja Glacier that the abundance (lake density; $\mathrm{km}^{2} \mathrm{~km}^{-2}$ ) of supraglacial lakes is similar to that on other glaciers in the SNP. Imja Lake was excluded from this calculation because it is dammed and thus its expansion is also affected by local characteristics such as the natural dam. In addition to the topographic conditions favouring the general development of glacial lakes on Imja Glacier, we are interested in additional factors that may have contributed to the lake expansion.

We speculate that the negative mass balance driven by rising temperatures leads to reductions in glacier velocity, surface elevation and slope. This favours the growth of lakes by creating space for lakes to form. The observed decrease in $V_{f}$ caused by a negative $\Delta Z$ in the ablation portion is the likely cause of the growth of Imja. Here we emphasize that the observed changes in glacier $V_{f}$ favour the formation and expansion of lakes (Benn and others, 2001). Furthermore, the decreasing $V_{\mathrm{f}}$ due to a more negative $\Delta Z$ in the upper ablation portion (Figs 7 and 8a) might explain the separation of the Amphu Lapcha branch from the rest of the ImjaLhotse Shar glaciers. Thus, the low velocity and high ablation rate of the glacier appear to be the two key factors linked to lake evolution.

\subsection{Climate change as a driver of glacier and lake variations}

The observed glacial factors responsible for the lake evolution - the decrease in $V_{\mathrm{f}}$ and the increase in glacial thinning (i.e. negative $\Delta Z$ ) - could be attributed to the changes in precipitation that influence accumulation and the temperature that controls the ablation of the glacier.

There are few ground stations supplying climatic data at higher elevations (above 3000 m a.s.l.). Salerno and others (2015), based on available ground station data, presented spatio-temporal variations in temperature and precipitation in this region during 1994-2013. They reported that at an elevation of $\sim 5000 \mathrm{~m}$ the annual minimum temperature $\left(0.072 \pm 0.011^{\circ} \mathrm{Ca}^{-1}\right)$ increased more than the maximum temperature $\left(0.009 \pm 0.012^{\circ} \mathrm{Ca}^{-1}\right)$ during 1994-2013. In the same period, the annual mean temperature increased by $0.044 \pm 0.008^{\circ} \mathrm{Ca}^{-1}$, contributed mainly by increases in November, December and April. They demonstrated, at an elevation of $\sim 5000 \mathrm{~m}$, a statistically significant $(-9.3 \pm$ $1.8 \mathrm{~mm} \mathrm{a}^{-1}$ ) decrease in annual total precipitation corresponding to a loss of $47 \%$ during the monsoon. Several previous studies indicated a weakening of the monsoon in the Himalaya in the last few decades (e.g. Yao and others, 2012; Palazzi and others, 2013), also influencing the local climate (Salerno and others, 2015). In contrast, Sharma and others (2000) reported a trend of increasing precipitation from 1948 to 1993 in the Dudh Koshi basin, and Salerno and others (2008) and Thakuri and others (2014) inferred that the increasing precipitation favoured glaciers on southfacing slopes and thus reduced glacier shrinkage until the 1990s. The subsequent weakening of monsoon precipitation most likely led to the decreasing $V_{f}$ of Imja Glacier from the 1990s to 2014 due to reduced accumulation on the glacier.

The decreasing glacier $\Delta$ Surf only at lower elevations before the 1990s and at much higher elevations after the 1990s (Fig. 6d) could be explained by the observed temperature and precipitation patterns during those periods. During the first period (1962-92), the glacier area loss at lower elevations could be due to increased temperatures, whereas increased precipitation would favour increases in the glacier area at higher elevations. During the second period (1992-2013), although the area loss at lower elevations continued due to increasing temperature, a significant decrease in precipitation may have resulted in the decreasing surface area at higher elevations (above $5750 \mathrm{~m}$ ). We should also remember the response time of the glaciers, but unfortunately we do not yet know their response times. Changes in climate (temperature and precipitation) influence the balance of the glaciers on a year-to-year basis, and ultimately determine glacier area through ice flow dynamics (Bahr and others, 1998; Cuffey and Paterson, 2010). The major changes in this glacier were around the snowline and in the accumulation zone, in particular in the steep up-glacier zone. We assume that in this zone the glacier responds quickly to the climate perturbation. Thus, in conclusion, before the 1990s, the glacier's surface area decreased primarily due to temperature changes, whereas after the 1990s the precipitation change augmented the loss in area by impacting the accumulation area.

Figure $4 \mathrm{C}$ presents the $0^{\circ} \mathrm{C}$ isotherms of the November maximum temperature in the area surrounding Imja Lake in 1994 and 2013. These isotherms were developed using vertical temperature gradients derived from the station data (Salerno and others, 2015). A significant shift (+168 m) of the isotherm is implied, from below the terminus of Imja Glacier in 1994 to above Imja Lake in 2013. From 1994 to 2013, significant shifts in the April $(+268 \mathrm{~m})$ and November $(+168 \mathrm{~m}) 0^{\circ} \mathrm{C}$ maximum temperature isotherms from lower to higher elevation crossed the lake, and the December isotherm shifted $(+201 \mathrm{~m})$ such that its location corresponds to the lake, thereby making the glacier more susceptible to melting. Even though the mean temperature has increased, 
no apparent change in glacial melting was observed due to increased mean temperature. In conclusion, in addition to decreasing precipitation that induced the lower velocities of the glacier, an increasing maximum temperature augmented melting of the glacier and likely controlled the evolution of the lakes. The significant increase in the April maximum temperature likely did not affect the evolution of the lake surface because during that month the temperature of the lake surface is below $0^{\circ} \mathrm{C}$ (frozen) and the lake is undergoing seasonal warming, based on the climate data (e.g. Fig. $3 \mathrm{~d}$ and $4 b)$.

\section{CONCLUSIONS}

Using multitemporal optical satellite imagery, we identified changes in Imja Glacier and the surface area of Imja Lake, and identified possible links between their recent evolution. From the 1960s to 2013, Imja Glacier shrank at an accelerating rate $\left(0.067 \pm 0.014 \mathrm{~km} \mathrm{a}^{-1}\right)$ and displayed a significant upward shift of the snowline $\left(\sim 9 \mathrm{~m} \mathrm{a}^{-1}\right)$, a retreat of the terminus $\left(\sim 44 \mathrm{~m} \mathrm{a}^{-1}\right)$ and an increase in debris cover $\left(0.026 \pm 0.004 \mathrm{~km}^{2} \mathrm{a}^{-1}\right)$. Furthermore, it recently displayed a thinning of glacier ice and an overall trend of decreasing flow velocities. The surface area of Imja Lake and the number of supraglacial lakes on Imja Glacier increased simultaneously with the shrinkage of the glacier from the 1960s to 2013.

We conclude that weakened monsoonal precipitation after the early 1990s resulted in decreased glacier flow velocities due to lower glacier accumulation and negative mass balances. These processes ultimately affect the evolution of the lake. In particular, increasing maximum temperatures during the post-monsoon months are likely driving rapid growth of the lake due to increased ablation of the glacier's surface near the lake. Imja Lake has grown due to shrinkage of Imja Glacier. Such a phenomenon may help to explain the evolution of all glacial lakes in this region. An examination of glacier properties together with lake variations across the region could therefore provide a regional perspective of the evolution of such lakes.

\section{ACKNOWLEDGEMENTS}

This work was supported by the Ministry of Education, Universities and Research (MIUR) through Ev-K2-CNR/ SHARE and CNR-DTA/NEXTDATA projects within the framework of the Ev-K2-CNR and Nepal Academy of Science and Technology (NAST) collaboration in Nepal. $\mathrm{S}$. Thakuri is the recipient of a doctoral research grant from the Intergovernmental Panel on Climate Change (IPCC) and the Prince Albert II of Monaco Foundation under the IPCC Scholarship Programme. T. Bolch acknowledges funding through Deutsche Forschungsgemeinschaft (DFG) and the European Space Agency (ESA) Glaciers_cci project.

\section{REFERENCES}

Bahr DB, Pfeffer WT, Sassolas C and Meier MF (1998) Response time of glaciers as a function of size and mass balance: 1 . Theory. J. Geophys. Res., 103(B5), 9777-9782 (doi: 10.1029/ 98JB0050)

Bajracharya B, Shrestha AB and Rajbhandari L (2007) Glacial lake outburst floods in the Sagarmatha region: hazard assessment using GIS and hydrodynamic modeling. Mt. Res. Dev., 27(4), 336-344 (doi: 10.1659/mrd.0783)
Basnett S, Kulkarni AV and Bolch T (2013) The influence of debris cover and glacial lakes on the recession of glaciers in Sikkim Himalaya, India. J. Glaciol., 59(218), 1035-1046 (doi: 10.3189/ 2013JoG12J184)

Benn D, Wiseman S and Hands K (2001) Growth and drainage of supraglacial lakes on debris-mantled Ngozumpa Glacier, Khumbu Himal, Nepal. J. Glaciol., 47(159), 626-638 (doi: 10.3189/172756501781831729)

Benn DI and 9 others (2012) Response of debris-covered glaciers in the Mount Everest region to recent warming, and implications for outburst flood hazards. Earth-Sci. Rev., 114, 156-174 (doi: 10.1016/j.earscirev.2012.03.008)

Bolch T, Buchroithner MF, Peters J, Baessler M and Bajracharya S (2008a) Identification of glacier motion and potentially dangerous glacial lakes in the Mt Everest region/Nepal using spaceborne imagery. Natur. Hazards Earth Syst. Sci., 8, 1329-1340 (doi: 10.5194/nhess-8-1329-2008)

Bolch T, Buchroithner M, Pieczonka T and Kunert A (2008b) Planimetric and volumetric glacier changes in the Khumbu Himalaya since 1962 using Corona, Landsat TM and ASTER data. J. Glaciol., 54, 592-600 (doi: 10.3189/ 002214308786570782)

Bolch T, Pieczonka T and Benn DI (2011) Multi-decadal mass loss of glaciers in the Everest area (Nepal Himalaya) derived from stereo imagery. Cryosphere, 5, 349-358 (doi: 10.5194/ tc-5-349-2011)

Brun $\mathrm{F}$ and 8 others (2015) Seasonal changes in surface albedo of Himalayan glaciers from MODIS data and links with the annual mass balance. Cryosphere, 9, 341-355 (doi: 10.5194/tc-9-3412015)

Cuffey KM and Paterson WSB (2010) The physics of glaciers, 4th edn. Academic Press, Amsterdam

Fujii Y and Higuchi K (1977) Statistical analysis of the forms of the glaciers in the Khumbu Himal. Seppyo, J. Jpn. Soc. Snow Ice, 39, 7-14

Fujita K, Sakai A, Nuimura T, Yamaguchi S and Sharma RR (2009) Recent changes in Imja Glacial Lake and its damming moraine in the Nepal Himalaya revealed by in situ surveys and multitemporal ASTER imagery. Environ. Res. Lett., 4, 045205 (doi: 10.1088/1748-9326/4/4/045205)

Gardelle J, Arnaud Y and Berthier E (2011) Contrasted evolution of glacial lakes along the Hindu Kush Himalayan mountain range between 1990 and 2009. Global Planet. Change, 75, 47-55 (doi: 10.1016/j.gloplacha.2010.10.003)

Gardelle J, Berthier E, Arnaud Y and Kääb A (2013) Region-wide glacier mass balances over the Pamir-Karakoram-Himalaya during 1999-2011. Cryosphere, 7, 1263-1286 (doi: 10.5194/ tc-7-1263-2013)

Global Land Ice Measurements from Space (GLIMS) and National Snow and Ice Data Center (NSIDC) (2005) GLIMS glacier database. National Snow and Ice Data Center, Boulder, CO (doi: 10.7265/N5V98602)

Hall DK, Bayr KJ, Schoner W, Bindschadler RA and Chien JYL (2003) Consideration of the errors inherent in mapping historical glacier positions in Austria from the ground and space (1893-2001). Remote Sens. Environ., 86, 566-577

Heid T and Kääb A (2012) Evaluation of existing image matching methods for deriving glacier surface displacements globally from optical satellite imagery. Remote Sens. Environ., 118, 339-355 (doi: 10.1016/j.rse.2011.11.024)

Höhle J and Höhle M (2009) Accuracy assessment of digital elevation models by means of robust statistical methods. ISPRS J. Photogramm. Remote Sens., 64, 398-406 (doi: 10.1016/ j.isprsjprs.2009.02.003)

Huss M (2013) Density assumptions for converting geodetic glacier volume change to mass change. Cryosphere, 7, 877-887 (doi: 10.5194/tc-7-877-2013)

Ichiyanagi K, Yamanaka MD, Muraji Y and Vaidya BK (2007) Precipitation in Nepal between 1987 and 1996. Int. J. Climatol., 27, 1753-1762 (doi: 10.1002/joc.1492) 
Kääb A and Vollmer M (2000) Surface geometry, thickness changes and flow fields on creeping mountain permafrost: automatic extraction by digital image analysis. Permafrost Periglac. Process., 11, 315-326 (doi: 10.1002/1099-1530(200012) 11:4<315::AID-PPP365>3.0.CO;2-J)

Kääb A, Lefauconnier B and Melvold K (2005) Flow field of Kronebreen, Svalbard, using repeated Landsat 7 and ASTER data. Ann. Glaciol., 42, 7-13 (doi: 10.3189/172756405781812916)

Kamp U, Bolch T and Olsenholler JA (2005) Geomorphometry of Cerro Sillajhuay, Chile/Bolivia: comparisons of DEMs derived from ASTER remote sensing data and contour maps. Geocarter Int., 20(1), 23-34

Koblet T and 6 others (2010) Reanalysis of multitemporal aerial images of Storglaciären, Sweden (1959-99) - Part 1: Determination of length, area, and volume changes. Cryosphere, 4, 333-343 (doi: 10.5194/tc-4-333-2010)

Kodama $\mathrm{H}$ and Mae S (1976) Flow of glaciers in the Khumbu region. Seppyo J. Jpn. Soc. Snow Ice, 38, 31-36

Luckman A, Quincey D and Bevan S (2007) The potential of satellite radar interferometry and feature tracking for monitoring flow rates of Himalayan glaciers. Remote Sens. Environ., 111(23), 172-181 (doi: 10.1016/j.rse.2007.05.019)

Manfredi EC and 16 others (2010) Solid waste and water quality management models for Sagarmatha National Park and Buffer Zone, Nepal: implementation of a participatory modeling framework. Mt. Res. Dev., 30, 127-142 (doi: 10.1659/MRDJOURNAL-D-10-00028.1)

McFeeters SK (1996) The use of the Normalized Difference Water Index (NDWI) in the delineation of open water features. Int. J. Remote Sens., 17(7), 1425-1432 (doi: 10.1080/ 01431169608948714)

Müller F (1968) Mittelfristige Schwankungen der Oberflaechengeschwindigkeiten des Khumbugletschers am Mount Everest. Schweiz. Bauz., 86(31), 569-573

Nakawo M, Yabuki H and Sakai A (1999) Characteristics of Khumbu Glacier, Nepal Himalaya: recent changes in the debriscovered area. Ann. Glaciol., 28, 118-122 (doi: 10.3189/ 172756499781821788)

Nuimura T, Fujita K, Yamaguchi S and Sharma RR (2012) Elevation changes of glaciers revealed by multitemporal digital elevation models calibrated by GPS survey in the Khumbu region, Nepal Himalaya, 1992-2008. J. Glaciol., 58, 648-656 (doi: 10.3189/ 2012JoG11J061)

Nuth C and Kääb A (2011) Co-registration and bias corrections of satellite elevation data sets for quantifying glacier thickness change. Cryosphere, 5(1), 271-290 (doi: 10.5194/tc5-271-2011)

Palazzi E, von Hardenberg J and Provenzale A (2013) Precipitation in the Hindu Kush-Karakoram-Himalaya: observations and future scenarios. J. Geophys. Res. Atmos., 118, 85-100 (doi: 10.1029/2012JD018697)

Paul F and Haeberli W (2008) Spatial variability of glacier elevation changes in the Swiss Alps obtained from two digital elevation models. Geophys. Res. Lett., 35, L21502 (doi: 10.1029/ 2008GL034718)

Paul F, Huggel C and Kääb A (2004) Combining satellite multispectral image data and a digital elevation model for mapping debris covered glaciers. Remote Sens. Environ., 89, 510-518 (doi: 10.1016/j.rse.2003.11.007)

Paul F and 24 others (2015) The glaciers climate change initiatives: methods for creating glacier area, elevation change and velocity products. Remote Sens. Environ., 162, 408-426 (doi: 10.1016/ j.rse.2013.07.043)

Pelto M (2011) Utility of late summer transient snowline migration rate on Taku Glacier, Alaska. Cryosphere, 5, 1127-1133 (doi: 10.5194/tc-5-1127-2011)

Peters J, Bolch T, Buchroithner MF and Bäßler M (2010) Glacier surface velocities in the Mount Everest area/Nepal using ASTER and Ikonos imagery. Proceedings of the 10th International Symposium on High Mountain Remote Sensing Cartography,
Kathmandu, Nepal. International Centre for Integrated Mountain Development, Kathmandu, 313-320

Quincey DJ and 6 others (2007) Early recognition of glacial lake hazards in the Himalaya using remote sensing datasets. Global Planet. Change, 56(1-2), 137-152 (doi: 10.1016/j.gloplacha. 2006.07.013)

Quincey DJ, Luckman A and Benn D (2009) Quantification of Everest region glacier velocities between 1992 and 2002, using satellite radar interferometry and feature tracking. J. Glaciol., 55(192), 596-606 (doi: 10.3189/ 002214309789470987)

Reynolds JM (2000) On the formation of supraglacial lakes on debris-covered glaciers. IAHS Publ. 264 (Symposium at Seattle 2000 - Debris-Covered Glaciers), 153-161

Richardson SD and Reynolds JM (2000) An overview of glacial hazards in the Himalayas, Quat. Int., 65/66(1), 31-47

Röhl K (2008) Characteristics and evolution of supraglacial ponds on debris-covered Tasman Glacier, New Zealand. J. Glaciol., 54(188), 867-880 (doi: 10.3189/002214308787779861)

Rounce DR and McKinney DC (2014) Debris thickness of glaciers in the Everest area (Nepal Himalaya) derived from satellite imagery using a nonlinear energy balance model. Cryosphere, 8, 1317-1329 (doi: 10.5194/tc-81317-2014)

Sakai A and Fujita K (2010) Formation conditions of supraglacial lakes on debris-covered glaciers in the Himalaya. J. Glaciol., 56(195), 177-181 (doi: 10.3189/002214310791190785)

Salerno F, Buraschi E, Bruccoleri G, Tartari G and Smiraglia C (2008) Glacier surface-area changes in Sagarmatha National Park, Nepal, in the second half of the 20th century, by comparison of historical maps. J. Glaciol., 54, 738-752 (doi: $10.3189 / 002214308786570926)$

Salerno F and 10 others (2010a) Experience with a hard and soft participatory modeling framework for social ecological system management in Mount Everest (Nepal) and K2 (Pakistan) protected areas. Mt. Res. Dev., 30, 80-93 (doi: 10.1659/MRDJOURNAL-D-10-00014.1)

Salerno F and 18 others (2010b) Energy, forest, and indoor air pollution models for Sagarmatha National Park and Buffer zone, Nepal: implementation of a participatory modeling framework. Mt. Res. Dev., 30, 113-126 (doi: 10.1659/MRD-JOURNAL-D10-00027.1)

Salerno F and 6 others (2012) Glacial lake distribution in the Mount Everest region: uncertainty of measurement and conditions of formation. Global Planet. Change, 92-93, 30-39 (doi: 10.1016/ j.gloplacha.2012.04.001)

Salerno F, Viviano G, Manfredi EC, Caroli P, Thakuri S and Tartari G (2013) Multiple carrying capacities from a managementoriented perspective to operationalize sustainable tourism in protected area. J. Environ. Manage., 128, 116-125 (doi: 10.1016/j.jenvman.2013.04.043)

Salerno $\mathrm{F}$ and 10 others (2015) Weak precipitation, warm winters and springs impact glaciers of south slopes of Mt Everest (central Himalaya) in the last 2 decades (1994-2013). Cryosphere, 9, 1229-1247 (doi: 10.5194/tc-9-1229-2015)

Scherler D, Leprince S and Strecker MR (2008) Glaciersurface velocities in alpine terrain from optical satellite imagery - accuracy improvement and quality assessment. Remote Sens. Environ., 112(10), 3806-3819 (doi: 10.1016/j. rse.2008.05.018)

Scherler D, Bookhagen B and Strecker MR (2011) Spatially variable response of Himalayan glaciers to climate change affected by debris cover. Nature Geosci., 4, 156-159 (doi: 10.1038/ NGEO1068)

Seko K, Yabuki H, Nakawo M, Sakai A, Kadota T and Yamada Y (1998) Changing surface features of Khumbu Glacier, Nepal Himalayas, revealed by SPOT images. Bull. Glacier Res., 16, $33-41$

Sharma KP, Moore B and Vorosmarty CJ (2000) Anthropogenic, climatic, and hydrologic trends in the Kosi basin, Himalaya. Climatic Change, 47, 141-165 (doi: 10.1023/A:1005696808953) 
Somos-Valenzuela MA, McKinney DC, Rounce DR and Byers AC (2014) Changes in Imja Tsho in the Mount Everest region of Nepal. Cryosphere, 8, 1661-1671 (doi: 10.5194/tc-81661-2014)

Tartari G, Salerno F, Buraschi E, Bruccoleri G and Smiraglia C (2008) Lake surface area variations in the North-Eastern sector of Sagarmatha National Park (Nepal) at the end of the 20th century by comparison of historical maps. J. Limnol., 67, 139-154

Thakuri S and 6 others (2014) Tracing glacier changes since the 1960s on the south slope of Mt Everest (central Southern Himalaya) using optical satellite imagery. Cryosphere, 8, 1297-1315 (doi: 10.5194/tc-8-1297-2014)

Thompson SS, Benn DI, Dennis K and Lukman A (2012) A rapidly growing moraine-dammed glacial lake on Ngozumpa Glacier, Nepal. Geomorphology, 145-146, 1-11 (doi: 10.1016/ j.geomorph.2011.08.015)
Toutin T (2008) ASTER DEMs for geomatic and geoscientific applications: a review. Int. J. Remote Sens., 29, 1855-1875 (doi: 10.1080/01431160701408477)

Watanabe T, Lamsal D and Ives JD (2009) Evaluating the growth characteristics of a glacial lake and its degree of danger of outburst flooding: Imja-Lhotse Shar glacier, Khumbu Himal, Nepal. Nor. Geogr. Tidssk./Nor. J. Geogr, 63, 255-267

Willis IC (1995) Intra-annual variations in glacier motion: a review. Progr. Phys. Geogr., 19(1), 61-106 (doi: 10.1177/ 030913339501900104)

Yamada T (1998) Glacier lake and its outburst flood in the Nepal Himalaya. (Monograph No. 1) Data Center for Glacier Research, Japanese Society of Snow and Ice, Tokyo

Yao T and 14 others (2012) Different glacier status with atmospheric circulations in Tibetan Plateau and surroundings. Nature Climate Change, 2(9), 663-667 (doi: 10.1038/nclimate1580) 